\title{
Analysis of Determinants of Farm Size Productivity among Small- Holder Cassava Farmers in South East Agro Ecological Zone, Nigeria
}

\author{
H. N. Anyaegbunam ${ }^{1 *}$, P. O. Nto ${ }^{2}$, B. C Okoye ${ }^{1}$ and T. U. Madu ${ }^{1}$ \\ ${ }^{1}$ National Root Crops Research Institute, Umudike, PMB7006, Umuahia, Abia State, Nigeria. \\ ${ }^{2}$ College of Agribusiness Michael Okpara University of Agriculture, Umudike, Abia State,
}

Nigeria.

Research Article

Received 20 $0^{\text {th }}$ July, 2011

Accepted $20^{\text {th }}$ October, 2011

Online Ready $16^{\text {th }}$ January 2012

\section{ABSTRACT}

Aims: To examine the socioeconomic characteristics of the farmers and determinants of farm size productivity among small-holder cassava farmers.

Study design: Time series data.

Place and Duration of study: The study was carried out in 2009 in the south-east agro ecological zone of Nigeria. April-June, 2009.

Methodology: A multistage randomized sampling method was used in selecting four states - Abia, Akwa Ibom, Imo and Cross River and then 240 cassava farmers in the area of study. Structured questionnaire and interview schedule were used to elicit information from the respondents. Information sought bordered on the socioeconomic characteristics of the respondents and input use. Analysis of data was carried out using log-linear regression model and descriptive statistics such as tables, percentages and mean.

Results: The results revealed that farm size was negative and significant at $1 \%$ and productivity of cassava increases with hired labour which is positively correlated with productivity at $1 \%$ level of probability. The coefficient of mode of occupation was positively correlated to productivity at $5 \%$. It signifies that full time farmers are more productive than part time farmers.

Conclusion: The results have shown that there is an inverse relationship between farm size and productivity. This call for policies aimed at redistribution of land targeted towards giving land to small-holder farmers in order to improve productivity. 
Keywords: Determinants; farm size; productivity; log-linear; cassava; small-holder farmers.

\section{INTRODUCTION}

Cassava is a staple food for over 200 million people in sub Saharan Africa. It is the most important source of carbohydrate for human consumption in the tropics after rice and maize. It is an important food and cash crop in several tropical African countries, especially Nigeria where it plays a principal role in the food economy (Agwu, 2007). In most African countries cassava is becoming an important cash crop that has high potential for use as an industrial raw material to manufacture starch, flour etc. (Nweke et al., 2004). The use of cassava in confectionery industries recently in Nigeria is new and fast gaining ground. Cassava is an important food crop in south-eastern Nigeria. It contributes about $15 \%$ of the daily dietary energy intake of most Nigerians and supplies about $70 \%$ of the total calories intake of about $60 \%$ people in Nigeria (Ezulike et al., 2006).

Nigeria is the world's largest producer of cassava, with about 45.75 million metric tonnes and ranks $2^{\text {nd }}$ after yam in extent of production among the root and tuber crops of economic value in Nigeria (FAO, 2007). Planting of high yielding and improved varieties has resulted in higher cash from crop farm. According to Ajibefun and Aderinola (2004), small holder food producers face two major types of risks and uncertainties: yield (Output) and price uncertainties. The former has to do with the environment and the nature of agricultural production while the later is linked partly with seasonality of production and partly infrastructural facilities and government policies.

One of the important economic arguments in favour of the equitable distribution of farmland is that small farms are more productive (Masterson, 2007). The majority of studies of agricultural productivity in developing counties support the view that there is an inverse relationship between productivity and farm size (Berry and Cline, 1979; Barrett, 1996; Heltberg, 1998; Hazarika and Alwang, 2003; Masterson, 2007; Gul Unal, 2008; Okoye et al., 2007, 2008a 2008b; Okoye 2009).

Land reform could contribute to improving both equity and efficiency in agriculture. One of the most common characteristics of the developing countries is the large share of agriculture in their economics. This feature produces the widely observed inverse size-yield relationship (IR) (Gul Unal, 2008).

Due to its policy implications for employment, efficiency, equity, and sustainability, IR has been one of the most important and hotly debated topics in agricultural economics for more than 40 years (Heltberg, 1998; Gul Unal, 2008). One critique leveled at the literature on the productivity-farm size relationship is that the measure used for land productivity, is inappropriate. Because it only compares total output to the size of the farm, ignoring other factors of production and input. Land productivity is said to be, at best, an incomplete measure of efficiency (Masterson, 2007). Therefore the objective of the study is to analyze the determinants of farm size productivity in south east agro ecological zone of Nigeria. 


\section{METHODOLOGY}

The study area was the south east agro-ecological zone of Nigeria. The south east agro ecological zone comprises of nine states namely Abia, Akwa lbom, Anambra, Bayelsa, Cross River, Ebonyi, Enugu, Imo and Rivers states.

A multistage randomized sampling technique was used in selecting 240 cassava farmers. In the first stage four states namely Abia, Akwa Ibom, Imo and Cross River States were randomly chosen. In the second stage, two agricultural zones were selected from each state giving a total of eight agricultural zones. In the third stage, 30 respondents (farmers) were randomly selected from each zone giving a total of 240 respondents.

Structured questionnaire and Interview schedule were used to elicit information from the respondents on labour, farm size, input use, output, capital and their socio-economic characteristics. Data were analyzed using descriptive statistics and the four functional forms of Regression model namely linear, exponential, Cobb- Douglas and log linear. The lead equation was selected based on certain econometric criteria.

\subsection{Analytical Procedures}

The four functional regression models- linear, Cobb-Douglas, Exponential and semi-log were the econometric models specified for explaining productivity in cassava production.

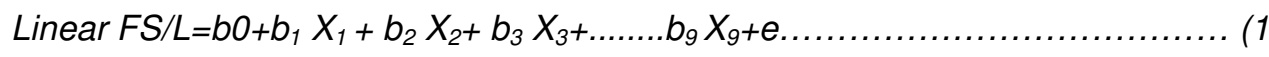

$$
\begin{aligned}
& \text { Cobb-Douglas: } L n F S / L=b 0+b_{1} \ln X_{1}+\ln X_{2}+b_{3} \ln X_{3}+b_{4} \ln X_{4}+\ldots \ldots \ldots b_{9} X_{9}+e \ldots \ldots \ldots \ldots \\
& \text { Exponential: } L n F S / L=b 0+b_{1} X_{1}+b_{2} X_{2}+b_{3} X_{3}+b_{4} X_{4}+\ldots \ldots b_{9} X_{9}+e \ldots \ldots \ldots \ldots \ldots \ldots \ldots \ldots \ldots \ldots \ldots \ldots \ldots \\
& \text { Log-Linear: } F S / L=b 0+b_{1} \ln X_{1}+B_{2} \ln X_{2}+b_{3} \ln X_{3}+b_{4} \ln X_{4}+\ldots . b_{9} \ln X_{9}+e
\end{aligned}
$$

Where $\mathrm{FS}=\mathrm{Farm}$ size in ha. L=Labour input for all activities (in man days); In=Natural logarithm; $X_{1}=A g e$ in years; $X_{2}=$ Household size; $X_{3}=$ Gender (Dummy variable: $1=$ male, $0=$ female); $X_{4}=$ Occupational status (Dummy variable: $1=$ full time farmer, $0=$ part time farmer); $X_{5}=$ farm size in ha; $X_{6}=$ fertilizer use in $\mathrm{kg} ; X_{7}=$ Hired labour in mandays; $X_{8}=$ family labour in mandays; $X_{9}=$ land ownership (Dummy variable: $1=$ market based, $0=$ Non-market based)

Farm size (Hectares)

Labour (Man days)

= farm size productivity ha/man days

\section{RESULTS AND DISCUSSION}

\subsection{Socioeconomic Characteristics}

The average statistics of the sampled cassava farmers are presented in Table 1. On the average, a typical cassava farmer in the zone is 49 years old, with 7 years of education, 24 years farming experience and average household size of 8 persons. 
The average land owned by the farmer was two hectares, hired labour used in mandays was 182 and family labour utilized was 121 mandays. Cassava production in the zone is a female dominated occupation as about $61 \%$ of the farmers are females. About $68 \%$ of the farmers were visited by the extension agents during the year of this study, while $84 \%$ of the farmers belong to one cooperative organization or the other

Table 1. Average Socioeconomics statistics of cassava farmers in the S/E zone

\begin{tabular}{lllll}
\hline SI.No. & Variables & Mean value & Maximum value & Minimum value \\
\hline 1 & Age & 48.72 & 80 & 20 \\
2 & Education (years) & 7.53 & 18 & 0 \\
3 & Household size & 8.90 & 40 & 1 \\
4 & Farming experience & 24.15 & 50 & 3 \\
5 & Land ownership & 2.13 & 20 & 0.02 \\
6 & Hired labour & 182.34 & 282.34 & 42 \\
7 & Family labour & 121.23 & 153.97 & 13 \\
8 & Gender (female) & $60.95 \%$ & & \\
9 & Extension contact & $68.48 \%$ & \\
10 & Farmers organization & $84.18 \%$ & \\
\hline \multicolumn{5}{c}{ Source: Field survey, 2009 } \\
\hline
\end{tabular}

\subsection{Econometrics Analysis}

Table 2 presents the results of the econometric analysis for cassava production in the zone. The semi-Log functional form was chosen as the best fit because of its high $R^{2}$ value and number of significant values in line with a priori expectations.

The productivity of cassava increases with hired labour which is positively correlated with productivity at $1 \%$ level of probability. This finding confirms an earlier work by Anyaegbunam et al. (2010). The study indicated that hired labour tends to be more productive than family labour because of the remuneration /wage involved. Most times hired labour may be under supervision by the farmer to make for efficient labour input and usage in the field

The coefficients of farm size and age are significant and negative at $1 \%$ and $5 \%$ respectively. This implies that productivity decreases with increase in farm size. Okoye et al. (2009) found that there exists an inverse relationship between farm size and productivity. It is expected that age will have a positive relationship with productivity; since age is used as a proxy for experience but the reverse is the case in this study. The implication is that any increase in age will decrease farm size productivity by $2.30 \%$. However, old age might be disadvantageous to agricultural production because most of the work is physically demanding (Ajibefun and Daramola, 2003; Ajibefun and Aderinola, 2004; Anyaegbunam et al., 2006, 2008; Okoye et al., 2009).

The coefficient of mode of occupation was positively correlated to productivity at $5 \%$. It signifies that full time farmers are more productive than part time farmers. Productivity significantly increases with the use of fertilizer al $10 \%$. This conforms to an apriori expectation that use of fertilizer increases output (Anyaegbunam et al., 2006) 
Table 2: Summary of regression analysis (four functional forms) on determinants of farm size productivity in cassava production in the S/E zone

\begin{tabular}{|c|c|c|c|c|}
\hline $\begin{array}{l}\text { Determinant } \\
\text { variables }\end{array}$ & $\begin{array}{l}\text { Linear } \\
\text { coefficients }\end{array}$ & $\begin{array}{l}\text { Exponential } \\
\text { coefficients }\end{array}$ & $\begin{array}{l}\text { Cobb-Douglas } \\
\text { coefficients }\end{array}$ & $\begin{array}{l}\text { Log-linear } \\
\text { coefficients }\end{array}$ \\
\hline Constant & $\begin{array}{l}102.7764 \\
(4.38)^{\star \star \star}\end{array}$ & $\begin{array}{l}4.5381 \\
(48.78)^{\star \star \star}\end{array}$ & $\begin{array}{l}131.758 \\
(-78.25)\end{array}$ & $\begin{array}{l}537.1551 \\
(-10.07)^{\star \star *}\end{array}$ \\
\hline$X_{1}$ & $\begin{array}{l}1.2676 \\
(2.98)^{\star * *}\end{array}$ & $\begin{array}{l}0.0018 \\
(3.59)^{* * *}\end{array}$ & $\begin{array}{l}46.4877 \\
(141.53)^{\star \star \star}\end{array}$ & $\begin{array}{l}23.9179 \\
(-2.30)^{\star *}\end{array}$ \\
\hline$X_{2}$ & $\begin{array}{l}0.2953 \\
(0.23)\end{array}$ & $\begin{array}{l}0.0054 \\
(-0.53)\end{array}$ & $\begin{array}{l}-0.0391 \\
(-0.45)\end{array}$ & $\begin{array}{l}5.6811 \\
(2.07)\end{array}$ \\
\hline$X_{3}$ & $\begin{array}{l}(-3.5751 \\
(-0.59)\end{array}$ & $\begin{array}{l}0.0252 \\
(0.26)\end{array}$ & $\begin{array}{l}0.5369 \\
(5.16)^{\star \star \star}\end{array}$ & $\begin{array}{l}-1.5571 \\
(-0.4)\end{array}$ \\
\hline$X_{4}$ & $\begin{array}{l}9.1126 \\
(1.16)\end{array}$ & $\begin{array}{l}0.0325 \\
(0.98)\end{array}$ & $\begin{array}{l}0.4822 \\
(3.69)^{* * *}\end{array}$ & $\begin{array}{l}8.4531 \\
(2.04)^{\star *}\end{array}$ \\
\hline$X_{5}$ & $\begin{array}{l}-116.1969 \\
(-13.38)^{\star \star *}\end{array}$ & $\begin{array}{l}0.0359 \\
(-23.97)^{\star \star \star}\end{array}$ & $\begin{array}{l}-0.3553 \\
(-2.18)^{\star *}\end{array}$ & $\begin{array}{l}-149.3846 \\
(-29.91)^{\star \star \star}\end{array}$ \\
\hline$X_{6}$ & $\begin{array}{l}-9.9550 \\
(-1.38)^{\star \star \star}\end{array}$ & $\begin{array}{l}0.0299 \\
(-0.16)\end{array}$ & $\begin{array}{l}-0.0343 \\
(-0.28)\end{array}$ & $\begin{array}{l}6.7153 \\
(1.73)^{*}\end{array}$ \\
\hline$X_{7}$ & $\begin{array}{l}0.8938 \\
(8.50)^{\star \star \star}\end{array}$ & $\begin{array}{l}0.0004 \\
(18.09)^{\star \star \star}\end{array}$ & $\begin{array}{l}0.1253 \\
(0.59)\end{array}$ & $\begin{array}{l}122.0003 \\
(18.17)^{\star * \star}\end{array}$ \\
\hline$X_{8}$ & $\begin{array}{l}-0.02542 \\
(-0.70)\end{array}$ & $\begin{array}{l}0.00015 \\
(-1.58)\end{array}$ & $\begin{array}{l}-0.0346 \\
(-0.28)\end{array}$ & $\begin{array}{l}-2.1393 \\
(-0.51\end{array}$ \\
\hline X9 & $\begin{array}{l}0.5922 \\
(0.07)\end{array}$ & $\begin{array}{l}0.0332 \\
(0.43)\end{array}$ & $\begin{array}{l}-0.2757 \\
(-2.03)^{\star *}\end{array}$ & $\begin{array}{l}1.2708 \\
(0.29)\end{array}$ \\
\hline $\mathrm{R}^{2}$ & 0.62 & 0.84 & 0.70 & 0.89 \\
\hline$F$ & 30.47 & 95.00 & 99.70 & 152.32 \\
\hline
\end{tabular}

Figures in parenthesis represents (t-ratios). ${ }^{* * *}=$ Significant at $1 \%,{ }^{* *}=$ significant at $5 \%,{ }^{*}=$ significant at $10 \% . X_{1}=$ Age in years; $X_{2}=$ Household size; $X_{3}=$ Gender (Dummy variable: $1=$ male, $0=$ female); $X_{4}=$ Occupational status (Dummy variable: $1=$ full time farmer, $0=$ part time farmer); $X 5$ =farm size in ha; $X 6=$ fertilizer use in $\mathrm{kg} ; X 7=$ Hired labour in mandays; $X 8=$ family labour in mandays; $X 9=$ land ownership(Dummy variable: $1=$ market based, $0=$ Non-market based)

Source: Regression Analysis of Survey, 2009.

\section{CONCLUSION}

Given the inverse relationship of farm size and productivity all factors related to farm size productivity such as hired labour, age, mode of operation and fertilize call for positive polices aimed at land reforms towards redistribution of land to make more land available to peasant and landless farmers in order to increase productivity and efficiency. Youths are therefore, encouraged to go into agriculture to bridge the encroaching generation gap in Agriculture.

\section{COMPETING INTERESTS}

Authors have declared that no competing interests exist. 


\section{REFERENCES}

Agwu, E.A., Anyaeche, C.I. (2007). Adoption of improved cassava varieties in 6 rural communities of Anambra State, Nigeria. African Journal of Biotechnology, 6, 089-098.

Anyaegbunam, H.N., Ogbnna, M.C., Asumugha, G.N. (2006). Determinants of adoption of cassava technology by small scale farmers in Abia State, Nigeria. Proceedings of the $40^{\text {th }}$ annual conference of the Agricultural society of Nigeria held at NRCRI Umudike $16^{\text {th }}-20^{\text {th }}$ October, 776-780.

Anyaegbunam, H.N., Okoye, B.C., Asumugha, G.N., Ogbonna, M.C., Madu, T.U., Nwakor, N., Ejechi, M.E. (2008). Labour productivity among small holder cassava farmers in south east agro ecological zone, Nigeria. African Journal of Agricultural Research, 5(21), 2882-2885. Available online at http /www academic journals.org/AJAR.

Ajibefun, J.A., Daramola, A.G. (2003). Determinants of technical and allocative efficiency of micro-enterprises, farm level evidence from Nigeria. African Development Bank, 353395.

Ajibefun, J.A., Aderinola, E.A. (2004). Technical efficiency and policy implications in traditional agricultural productions. Paper presented at Bi-annual Research workshop of AERC Nairobi, Kenya, $24^{\text {th }}-29^{\text {th }}$ May.

Barret, C.B. (1996). On price risk and Inverse farm size-productivity relationship. Journal of Development Economics, 5(369), 193 -215.

Berry, A., Cline, W. (1979). Agrarian structure and productivity in developing countries, Baltimore: Johns Hopkins University.

Bharadwaj, K. (1974). Production conditions in Indian agriculture: A study based on farm management surveys, Cambridge U.K. A Computer program for stochastic frontier production and cost function estimation. Department of Economics, University of New England, Armidale, Australia.

Cornia, G.A. (1985). Farm size, land yields and the agricultural production function. An analysis for fifteen developing countries. World development, 13(4), 513 - 514.

Ezulike, T.O., Nwosu, K.I., Udealor, A., Eke-Okoro, O.N. (2006). A Guide to cassava production in Nigeria Extension guide No 16. National Root Crops Research Institute, Umudike, Nigeria, 10.

FAO. (2007). Food and Agricultural Organization, Database Results.

Gul Unal, F. (2008). Small is beautiful; evidence of an inverse relationship between farm size and yield in Turkey. Working paper No.551. The levy Economics Institute, P. O. Box 5000. Annandale-on-Hudson, NY 12504 - 5000.

Hazirika, G., Alwang, J. (2003). Access to credit, plot size and cost inefficiency among small holder tobacco cultivation in Malawi. Agricultural Economics, 2(9), 99 - 109.

Heltberg, R. (1998). Rural market imperfections and the farm size-productivity relationship: evidence from Pakistan. World Development, 26(10), 1807 - 1826.

Masterson, T. (2007). Productivity, technical efficiency, and farm size in Paraguayan agriculture. The levy Economics Institute of Bard College. Working paper No. 490, Feb, 2007.

Nweke, F.I., Enete, A.A. (1999). Gender surprises in food production, processing and marketing with emphasis on cassava in Africa. COSCA working paper No. 19 IIT, Amlbadan, Nigeria.

Nweke, F.I. (2004). Processing potential for cassava production growth in sub Saharan Africa. COSAC working paper NOII, collaborative study of cassava in Africa, IITA, Nigeria.

Okoye, B.C., Onyenweaku, C.E., Asumugha, G.N. (2007). Allocative efficiency of small holder cocoyam farmers in Anambra state, Nigeria. The Nigeria Agricultural Journal, $38,70-81$ 
Okoye, B.C., Onyenweaku, C.E., Ukoha, O.O., Asumugha, G.N., Aniedu, O.C. (2008). Determinants of labour productivity on small-holder cocoyams in Anambra state, Nigeria. Academic Journal Scientific Research and Essay, 3(11), 559-561.

Okoye, B.C., Onyenweaku, C.E., Agwu, A.E. (2008). Technical efficiency of small- holder cocoyam farmers in Anambra state, Nigeria: Implications for agricultural extension policy. Paper presented at the $13^{\text {th }}$ Annual Conference of the Agricultural Extension of Nigeria (AESON) Book of Abstracts, Held at the Michael Okpara University of Agriculture, Unudike, April, 8 -11, 2008.

Okoye, B.C., Agbaeze, C.C., Asumugha, G. N., Aniedu, O.C., Mbanaso, E.N.A. (2009). Small is beautiful: empirical evidence of an inverse relationship between farm size and productive efficiency in small holder cassava production in Ideato North LGA of Imo state. http://mpra.ub.uni-muenchen.de/17418/.

RMRDC. (2004). Raw materials research and development council. Cassava: Report on survey of selected agricultural raw materials in Nigeria, pp. 210.

(c) 2012 Anyaegbunam et al.; This is an Open Access article distributed under the terms of the Creative Commons Attribution License (http://creativecommons.org/licenses/by/3.0), which permits unrestricted use, distribution, and reproduction in any medium, provided the original work is properly cited. 